\title{
Globalization Impact on Investments: Challenges and Solutions
}

\author{
Povilas Švogžlys ${ }^{1}$, Eugenijus Chlivickas ${ }^{2}$ \\ ${ }^{1,2}$ Faculty of Business Management, Vilnius Gediminas Technical University, Vilnius, Lithuania \\ E-mails: ${ }^{1}$ povilas.svogzlys@gmail.com (corresponding author);'eugenijus.chlivickas@vgtu.lt
}

Received 12 February 2017; accepted 5 April 2017

\begin{abstract}
Globalization is certainly a widely debated topic nowadays. It is one of the main features characterizing contemprorary society. This phenomenon affects the most significant social, economic, technological, political and cultural processes. Rising living standarts and technological progress are changing consumer behavior, needs and main priorities. Purchasing decisions are determined not only by price or physical and technical characteristics of the item, but also by global trends which can directly affect consumer behavior. This publication presents analysis of globalization impact on investments. Given the fact that the real estate is one of the most important investments in our life, the study has focused on the European Union residential real estate markets. The methods of scientific literature analysis, statistical data evaluation and synthesis has been applied for the research presented in this paper.
\end{abstract}

Keywords: European Union, consumer behavior, globalization, investments, real estate.

JELClassification: F60, E22.

Conference topic: Internationalization Processes: Contemporary Challenges.

\section{Introduction}

Twenty years ago the term of globalization was a little-known, however, these days, the term has come to the interest of many. This concept has spread into economic and political debate is used in business and in the media. The rapid pace of life in modern society, international changes in the economy, politics, and technology, seeking to promote the updating and continuous improvement of the multifaceted concepts of globalization. Many authors view globalization as a very important process, which changes the outlook of society or international processes.

The real estate sector is one of the most important structural elements that make up a favourable environment for economic development, as well as the overall financial stability, attracting international investment. In the context of globalization processes, this sector is more often than not affected by external threats, which have an immense influence on its further development. Manifestations of terrorism, corruption, refugee crisis or British withdrawal from the European Union - all of this is only a small part of the external factors that have a major impact in shaping consumers' needs or interests. Due to the importance of today's current affairs, users are often more cautious when purchasing items of higher value, trying to better assess their capabilities to carry out their obligations to financial institutions in the future. All this is reflected in global financial crisis which occurred five years ago: the majority of the real estate market participants began to look more closely into the major abnormalities and risk factors (financial, legal and business environment), which may lead to fluctuations in price and supply.

The objective of this study is to analyse external factors on the European Union's real estate investments based on literature and statistical data analysis.

The main objectives of the study:

To analyse the globalization issues examined in scientific literature;

Examine external factors that affect investments in residential real estate;

Present a forecast for the residential real estate market in 2017.

The problem of the study - can the emergence of external factors have a decisive impact on real estate investments in the context of globalization?

Object of research - European residential real estate investments.

Methodology of research. The following methods were used in the analysis of the peculiarities of globalization and external factors on the European Union's real estate investments: analysis of scientific literature, statistical comparison and synthesis.

(C) 2017 P. Švogžlys, E. Chlivickas. Published by VGTU Press. This is an open-access article distributed under the terms of the Creative Commons Attribution (CC BY 4.0) License, which permits unrestricted use, distribution, and reproduction in any medium, provided the original author and source are credited. 


\section{The concept of globalization: modern discourses}

Robinson (2007) has comprehensively discussed the the concept of globalization and the key features of this process in his article titled "Theories of Globalization". The author points out that globalization is one of the most important keys to many unanswered questions. It should also be noted that the topic is particularly relevant in the 21 st century, the research of which should be given more attention. This international phenomenon is reconfiguring the traditional way of thinking about the world, as well as the traditional understanding of human cultural evolution. The publication distinguishes 7 paradigms of globalization, which are clearly identified in the current impact of globalization and its importance to modern society:

- The theory of the world system. This theory investigates the social evolution of public systems, as well as their influence on each other.

- The theory of global capitalism. This theory makes it possible to see globalization as a system of global capitalism. Three main features were included in this theory: international production, transnational capitalists and multicultural states. These particular elements allowed for a clearer understanding of the evolution of capitalism and its role in the context of globalization.

- The theory of network society. Over the past five years, information technology has evolved rapidly. People are spending more and more time on the Internet. This development of information technology encourages users to publicize their personal data, buy goods on-line, or to make use of new technological solutions (mobile phones, tablet computers). Any technological improvement processes include government agencies, which are forced to adapt to the constantly changing needs of the people, facilitating information retrieval and dissemination.

- The theory of space, location and globalization. This theory describes how the processes of globalization may vary depending on the space, territoriality and geographical aspects. This means that the country-specific location has a significant influence on society's adaptation to all multicultural factors.

- The theory of internationalization. This theory states that, over the years, more and more objects, processes, and factors become international. At present, such things as a person's sexual orientation, youth subcultures, or even musical interests are already perceived through a mutual multicultural prism. As globalization evolves, people begin to show more tolerance towards each other, so the need for a particular religion or ethnicity is no longer distinguishable.

- The theory of modernity and post-modernity. This is a theory that has two main approaches. One of them states that we live in the modern world, which moves in concert with all the innovation, social, and technological developments, and other approach indicates that we live in a post-modern world where factors such as progress, rationality, and objectivity are not as greatly emphasized.

- The theory of global culture. This theory examines the cultural divide. Often, the differences in language, customs, and mentality between people from different countries result in communication challenges. However, the fast development of the processes of globalization makes one forget such problems, as people begin to use languages recognized as international (English, French, German, and so on) (Robinson 2007).

Varma and Gill (2010) state that globalization is a new economic, political, and cultural type, encouraging us to live in a world where a national state is no longer so important, therefore being less significant as an economic unit. In this world, important roles are taken by the needs of the people and well known brands, which are created by international organizations (Varma, Gill 2010). An investigation showed that globalization can take place selectively: some segments of the economy can be included or excluded from the general networks characterizing information or property. The authors of the article state that a critical characteristic of contemporary globalization is the process of urbanization, which is characteristic to all urban cities.

The approach presented by Scholte (2005) is widely divergent in the analysis of modern scientific works. The author notes that the definition of globalization should reveal new content, but not to replicate what is already known. Any definition is relative, because it reflects the historical moment, cultural and geographical environments, the paradigmatic approach of an author, his experience and expectations. Globalization can be understood as social relations between people of international significance. Over the past 50 years they have intensified. This is seen in political decisions, international economy and innovative development. Public cultural and social developments, as well as ambitions go hand in hand with scientific and technological progress, shows that globalization is an important factor in the trends of life. Globalization has led to the emergence of change in national, state and territorial context. This process can bring many positive results with regard to human security, social equality and democracy in the state (Scholte 2005).

Giddens (2005) observed globalization from a social science perspective, defining it as the growing of different nations in the world, regional and internal dependence between countries, caused by the social and economic relations which are increasingly covering the world. Globalization is transforming the nature of our daily experience, forcing us to redefine other intimate and personal aspects of our lives. Although this process is most frequently depicted as simply an economic phenomenon, one should not forget the particular significance of its formation to global technological progress, as well as political, social and cultural factors (Giddens 2005). 
Another significant researcher of globalization processes - Ravenhill (2011) - efforts to explain the terminology of globalization, as well as its importance and issues in his book "Global political economy". The author pointed out that globalization can be identified as one of the main features characterizing the contemporary society. It creates preconditions for the formation of changes in all areas of life. It is also one of the most important factors affecting the formation of economic, cultural and technological progress. Globalization is one of the world's economic components, which leads to the growth of the market and favourable cooperation between the market participants (Ravenhill 2011).

Held et al. (2002) identified several key factors that allow to form a precise definition of globalization:

- Globalization may have a significant impact on the distribution of power and wealth between countries or within a country.

- The processes of globalization are reflected in all areas of life: cultural, economic, political, legal, environmental, technological development and even warfare. These processes have a significant impact on the daily institutional or social activities.

- The effects of globalization may be direct towards counties, when the type of their activity is changed, or indirect when the context and balance of powers is changed.

- Historical patterns in globalization can be described in four time elements: extensiveness, relations between the intensity, flow speed and mutual influence.

Thus, globalization can be defined as a multidimensional phenomenon, which promotes human activity structure transformation, as well as the global acceleration of social, economic, technological and political processes (Held et al. 2002).

Steger (2013) conveys the concept much more simply, interpreting it as a multi-faceted process involving global, regional and local aspects of social life. Globalization can be used to describe many social processes which are changing our current social conditions to global. People's understanding of decreasing geographical borders and distance values promotes the feeling that they are part of the global world. In its essence, globalization is changing the human forms of communication. Globalization is a multi-social processes set to create, multiply, differentiate and intensify social interdependence, at the same time allowing for a deeper understanding of closer relationship between what's local and distant (Steger 2013).

Bauman (2007), one of the most famous sociologists of the second half of the twentieth century, tried to look at the processes of globalization from the human perspective. According to the author, the phenomenon of globalization is much more complicated than it seems at first glance. Revealing the social roots of the globalization process and the consequences of attempts to clear the fog that surrounds this term that may as well explain the human existence. Globalization is not what we all, or at least the most inventive, want or hope to do. Globalization is what is happening to all of us (Bauman 2007). Thus, the processes of globalization, regardless of their locality, affect all of us in any case. Selected writers describe quite different processes of globalization and their implications for the present day society. Summarized respective theoretical approaches to globalization processes are provided in Table 1.

Table 1. Theoretical aspects of globalization: the author's opinion comparison (Source: composed by the authors)

\begin{tabular}{|c|c|c|c|c|c|c|c|c|}
\hline & $\begin{array}{c}\text { W. I. } \\
\text { Robinson }\end{array}$ & $\begin{array}{c}\text { S. } \\
\text { Varmi }\end{array}$ & $\begin{array}{l}\text { J. A. } \\
\text { Scholte }\end{array}$ & $\begin{array}{l}\text { A. } \\
\text { Giddens }\end{array}$ & $\begin{array}{c}\text { J. } \\
\text { Ravenhill }\end{array}$ & $\begin{array}{l}\text { D. Held } \\
\text { et al. }\end{array}$ & $\begin{array}{l}\text { M. B. } \\
\text { Steger }\end{array}$ & $\begin{array}{c}\text { Z. } \\
\text { Bauman }\end{array}$ \\
\hline $\begin{array}{l}\text { Globalization definition consists of a } \\
\text { smaller theoretical units }\end{array}$ & $\mathrm{X}$ & & & & & $\mathrm{X}$ & & \\
\hline Social aspect & $\mathrm{X}$ & & $\mathrm{X}$ & $\mathrm{X}$ & $\mathrm{X}$ & $\mathrm{X}$ & $\mathrm{X}$ & $\mathrm{X}$ \\
\hline Geographical aspect & $\mathrm{X}$ & & $\mathrm{X}$ & & & $\mathrm{X}$ & $\mathrm{X}$ & $\mathrm{X}$ \\
\hline The impact of globalization & & & & & & & & $\mathrm{X}$ \\
\hline $\begin{array}{l}\text { Globalization interface with modern } \\
\text { economic and political processes }\end{array}$ & & $\mathrm{X}$ & $\mathrm{X}$ & $\mathrm{X}$ & $\mathrm{X}$ & $\mathrm{X}$ & & \\
\hline $\begin{array}{l}\text { Globalization interface with modern } \\
\text { technological processes }\end{array}$ & $\mathrm{X}$ & $X$ & $\mathrm{X}$ & $\mathrm{X}$ & $\mathrm{X}$ & $\mathrm{X}$ & & \\
\hline
\end{tabular}

The research showed that in the second half of the twentieth century the term globalization has become widely used not only in different areas of life, but it has become a universally important subject for research. Because of its uniqueness and significance this process has become extremely relevant for modern sociologists, theoreticians and representatives of different areas of academic activity. It is important to note the fact that globalization is a rapidly changing process, so this term must be continuously improved under the current realities and market trends. In summary, following the insights of the authors, globalization can be defined as an ongoing development of communication between all areas of life (social, cultural, economic, political, technological), their deepening and accelerating on a 
global scale. These are continuous processes in which various standards, norms, or activities in various fields are disseminated, assimilated and updated. Examination of the theoretical approaches of the 8 authors shows that the concept of globalization is usually marked by the social aspect. Its importance can be explained by the fact that human interaction, relationships and increasing societal demands, naturally accelerates the globalization processes. The authors that have distinguished the importance of technological factors noted that the technology refers to the actual progress of globalization: innovative applications of potential customer needs, rapid innovation diffusion, as well as the global scale and speed of human interaction. The importance of the geographic aspect was distinguished by 5 authors. They pointed out that the geographical location plays a major role in adapting to rapidly evolving multicultural changes. Exactly the same number of authors noted the role of modern economic and political processes, the fact that they had carried out a huge operation beyond national borders, affecting the global production processes. A part of the author draw attention to the significant rise in the volume of capital on the global movement.

\section{External factors affecting the investments of real estate}

With the development of globalization, the real estate development cycle is also evolve, more factors that could influence it emerge. Cycle speed, the total number of participants and the quality of the intermediate elements depends on these factors. Changes in legal, energetic and technological standards slow this cycle down, and changes in consumer demand force it to spin faster. Frequent participant of the process forgets that there are a number of critical factors that can determine the future prices not only for housing but also for the whole region of real estate. These factors play a major role for sales, project development and in potential buyers selection of buying one or another kind of property. In evaluating the real estate market environment in the European Union, it is necessary to find out how consumer needs and behaviour are shaped by external factors emerging in the global space.

“BREXIT" referendum. After 43 years of membership in the European Union, British citizens voted for withdrawal from the union on the 23 of June, 2016. The referendum went down in history not only because of the British division into two opposing camps, but also for the impact on the foreign markets. If the residents of the United Kingdom decide to leave the European Union, the investors and entrepreneurs will lose confidence in the current economic situation. The financial markets were ready for different voting results, so market participants are panicking - exchange rates are ranging, major global banks take the appropriate action (Bryson 2016). Financial market turbulence reduces the financial stability and propensity to invest in the euro zone. The uncertainty prevailing due to market volatility may reduce banks' willingness to lend to individuals and riskier real estate projects. It is likely that the World Bank catalyst (protective) action will limit the negative impact of falling markets to lending. In any case, the security measures should be taken by both sides: investors must prudently select potential investment markets and banks must further assess the risks involved in granting loans. Withdrawal from the European Union should also slow down the internationally recognized energy building certification processes: constructed buildings, perhaps, will not be subject to B, A or A + energy class standards. It can be assumed that over the years the United Kingdom will adopt its own building assessment system. The fact that the decline in workers' remittances from the United Kingdom may adversely affect the recovery in housing market activity may also be distinguished. Over time, the labour migration will refocus on other countries - an increase of migration to Norway, Denmark, Ireland should be observed, therefore restoring the amount of foreign transfers. Lack of stable British real estate market may bring buyers to look for new investment areas. A study carried out by "Cushman \& Wakefield" (2016) predicted that due to the favourable investment environment and high real estate supply those areas might be: Germany, France, Portugal and Spain. This is illustrated by the factual data of the third quarter of 2016: the total real estate created value in the UK is decreasing, while in countries such as Germany, France, Portugal and Spain, on the contrary - it is increasing (Eurostat 2017b).

Terrorism. The terrorist acts that have occurred in Western Europe had a significant influence on not only the tourism sector in countries such as France and Germany, but also impacted the real estate markets of these countries. In their 2015 report, "Wells Fargo" private bank suggests real estate investors to monitor the progress of economic recovery - especially in Western Europe. The Islamic state will be a reduced risk factor that should not have much impact on the investments in Europe (Wells Fargo 2015). Representatives of the Bank recommend to maintain the long-term investment plans and continue to choose such regions as the United States or Europe. Comparing the data from the third quarter of 2015 and 2016, it can be observed that the general geopolitical situation in the EU is becoming more and more relevant. Most of the respondents identify terrorism as a problem inspiring even greater threat than the economic situation these days (see Table 2). The major European Union countries Terrorism indices have deteriorated (growth indicator shows a deterioration): Germany (+1.582), France $(+2.020)$, Denmark $(+2.061)$, Sweden $(+1.858)$, Finland (+2.377) (Institute for Economic \& Peace 2016). These results may be the outcome of large incoming flows of refugees and the risks of processes related to their integration. Todd Sandler (2014) presents an analytical study ofterrorism impact on major stock markets. Terrorist attacks only affect the stock value of specific companies for a short period of time, having no long term effects on the market (Sandler 2014). Brodeur (2015) sought to find substantial differences between successful and unsuccessful terrorist attacks on the national economy through empirical study. Successful terrorist attacks do not have long-term effects, so it can be assumed that this is a factor causing short-term impact (Brodeur 2015). 
Refugee crisis. European Union countries received 358 thousand applications for sanctuary in the third quarter of 2016 - this is 50 thousand more than in the second quarter (Eurostat 2017a). Most applications were directed to EU countries such as Germany, France, Italy, England and Greece. Germany is currently satisfying most applications, compared with those populations. The largest amount of applications during the third quarter of 2016 came from: Syria (87915), Afghanistan (62070), Iraq (36430), Nigeria (15535) and Pakistan (14250). Comparing these data to the second quarter in 2016, we can see an increase: Afghanistan (23\%), Iraq (6\%), Nigeria (63\%) and Pakistan (8\%). During the year 2016, more than 300 thousand refugees came to Europe, of which 3.5 thousand were killed or disappeared (UNHCR 2016). On the basis of the standard "Eurobarometer 84" survey, it can be seen that the majority of respondents of the survey carried out in the third quarter of 2015 identified immigration as the main problem affecting the EU. According to the 2016 "Eurobarometer 86" survey of the same period, 13\% less of the respondents identified immigration as a problem; however this problem was still the most significant (see Table 2). The scale of the problem can be seen from the budget that the EU members intend on dedicating during the 2015-2017 period. European Commission has proposed to dedicate 6 billion euros to the refugee problem in 2017, for the European Union and the countries from which the refugees come. These funds are to be used to assist Member States to resettle refugees in the EU, creating reception centres, to promote the integration of foreigners inside the country and to create a proper non-return system (European Commission 2016b). In view of the increasing flow of refugees arriving, there are some changes in this draft budget:

- The aim will be to fund effective measures to prevent illegal migration and human trafficking.

- A large part of the funds will be allocated to enhance crime prevention, as well as to strengthen the counterterrorism activities (European Commission 2016b).

Large allocation of assistance to foreigners already causes resentment in groups of social and economic exclusion: pensioners, people who live on benefits and families in long queues waiting for social housing (Rajaram 2015). It can be assumed that the majority of real estate developers stop objects under development next to the areas where large groups of refugees will be concentrated. This can lead to a chain reaction - decrease in the number of buyers, specific areas will losing their popularity. In this case, if less business centres are built, metropolitans will lose a large part of foreign direct investments. The problem of refugees may be observed in the United States. During the years 20092015, United States suffered 12 armed terrorist attacks, initiated by persons who have received sanctuary in different states (Jones 2015). The author notes that the number of terrorist attacks calls for a renewed review of the sanctuary seekers reception and integration regulation.

Table 2. Standart Eurobarometer poll, held in $20153^{\text {rd }}$ quarter and $20163^{\text {rd }}$ quarter

(Source: composed by the authors of the basis of Standart Eurobarometer 842015 and 86 2016a data)

\begin{tabular}{|c|c|c|c|c|c|c|}
\hline \multicolumn{7}{|c|}{ What do you think are the two most important issues facing the European Union at the moment? } \\
\hline \multirow[b]{2}{*}{ EU State } & \multicolumn{3}{|c|}{ The main problems identified in $20153^{\text {rd }}$ quarter } & \multicolumn{3}{|c|}{ The main problems identified in $20163^{\text {rd }}$ quarter } \\
\hline & Immigration & Terrorism & $\begin{array}{l}\text { Economic } \\
\text { situation }\end{array}$ & Immigration & Terrorism & $\begin{array}{c}\text { Economic } \\
\text { situation }\end{array}$ \\
\hline EUaverage & $58 \%$ & $25 \%$ & $21 \%$ & $45 \%$ & $32 \%$ & $20 \%$ \\
\hline Belgium & $61 \%$ & $25 \%$ & $22 \%$ & $43 \%$ & $33 \%$ & $22 \%$ \\
\hline Malta & $74 \%$ & $38 \%$ & $13 \%$ & $65 \%$ & $45 \%$ & $10 \%$ \\
\hline France & $49 \%$ & $27 \%$ & $22 \%$ & $36 \%$ & $35 \%$ & $21 \%$ \\
\hline Italy & $49 \%$ & $20 \%$ & $25 \%$ & $49 \%$ & $23 \%$ & $23 \%$ \\
\hline Portugal & $31 \%$ & $23 \%$ & $23 \%$ & $23 \%$ & $23 \%$ & $24 \%$ \\
\hline Luxembourg & $55 \%$ & $25 \%$ & $18 \%$ & $42 \%$ & $39 \%$ & $16 \%$ \\
\hline Germany & $76 \%$ & $15 \%$ & $18 \%$ & $50 \%$ & $31 \%$ & $14 \%$ \\
\hline Croatia & $52 \%$ & $26 \%$ & $15 \%$ & $43 \%$ & $42 \%$ & $13 \%$ \\
\hline Cyprus & $49 \%$ & $20 \%$ & $33 \%$ & $47 \%$ & $35 \%$ & $28 \%$ \\
\hline Austria & $66 \%$ & $15 \%$ & $17 \%$ & $39 \%$ & $22 \%$ & $20 \%$ \\
\hline Hungary & $68 \%$ & $34 \%$ & $15 \%$ & $65 \%$ & $40 \%$ & $15 \%$ \\
\hline Netherlands & $75 \%$ & $24 \%$ & $25 \%$ & $56 \%$ & $33 \%$ & $23 \%$ \\
\hline Romania & $47 \%$ & $43 \%$ & $15 \%$ & $36 \%$ & $34 \%$ & $15 \%$ \\
\hline Ireland & $48 \%$ & $30 \%$ & $18 \%$ & $41 \%$ & $33 \%$ & $21 \%$ \\
\hline Finland & $58 \%$ & $20 \%$ & $25 \%$ & $38 \%$ & $22 \%$ & $23 \%$ \\
\hline
\end{tabular}


What do you think are the two most important issues facing the European Union at the moment?

\begin{tabular}{|c|c|c|c|c|c|c|}
\hline \multirow[b]{2}{*}{ EU State } & \multicolumn{3}{|c|}{ The main problems identified in $20153^{\text {rd }}$ quarter } & \multicolumn{3}{|c|}{ The main problems identified in $20163^{\text {rd }}$ quarter } \\
\hline & Immigration & Terrorism & $\begin{array}{c}\text { Economic } \\
\text { situation }\end{array}$ & Immigration & Terrorism & $\begin{array}{c}\text { Economic } \\
\text { situation }\end{array}$ \\
\hline Greece & $52 \%$ & $13 \%$ & $36 \%$ & $41 \%$ & $27 \%$ & $33 \%$ \\
\hline Czech Republic & $76 \%$ & $32 \%$ & $12 \%$ & $63 \%$ & $47 \%$ & $9 \%$ \\
\hline Sweden & $74 \%$ & $18 \%$ & $28 \%$ & $57 \%$ & $20 \%$ & $25 \%$ \\
\hline United Kingdom & $61 \%$ & $34 \%$ & $23 \%$ & $42 \%$ & $26 \%$ & $24 \%$ \\
\hline Bulgaria & $61 \%$ & $38 \%$ & $14 \%$ & $62 \%$ & $42 \%$ & $12 \%$ \\
\hline Poland & $54 \%$ & $28 \%$ & $11 \%$ & $50 \%$ & $43 \%$ & $15 \%$ \\
\hline Slovenia & $74 \%$ & $17 \%$ & $19 \%$ & $58 \%$ & $36 \%$ & $16 \%$ \\
\hline Latvia & $66 \%$ & $39 \%$ & $14 \%$ & $57 \%$ & $45 \%$ & $17 \%$ \\
\hline Slovakia & $72 \%$ & $39 \%$ & $10 \%$ & $51 \%$ & $40 \%$ & $11 \%$ \\
\hline Estonia & $79 \%$ & $32 \%$ & $17 \%$ & $70 \%$ & $41 \%$ & $15 \%$ \\
\hline Lithuania & $64 \%$ & $28 \%$ & $18 \%$ & $53 \%$ & $44 \%$ & $14 \%$ \\
\hline Denmark & $76 \%$ & $21 \%$ & $22 \%$ & $59 \%$ & $21 \%$ & $23 \%$ \\
\hline Spain & $39 \%$ & $24 \%$ & $24 \%$ & $32 \%$ & $33 \%$ & $31 \%$ \\
\hline
\end{tabular}

Corruption. Real estate and construction sectors are one of the most corrupt in the world. Big liabilities related to real estate (loans, credits), the desire to pay lower fees or the need to speed up the construction process in the municipalities allow for future development of corruption in the sector. Illegally earned cash is used in large scale real estate buying and selling processes (KPMG 2011). Once in a 2 year period, the research centre "Jones Lang LaSalle" presents the global real estate market transparency indices for 102 countries. England, Australia, Canada, the United States and France were identified as the most transparent in the 2016 list. The most corrupt were Tanzania, Belarus, Mozambique and Guatemala (JLL 2016). Judging from the test results, it can be assumed that the economic situation is the most important factor in determining the level of corruption in the country. Following the results of the European Commision research (2014a) in the great majority of EU countries people were convinced that the authorities permitting construction were the most corrupt (see Table 3). In the Netherlands it the largest $-69 \%$, while in Denmark it is 2.7 times lower. $39 \%$ of the participants from Lithuania were sure that the real estate and construction markets are corrupt. This is only $4 \%$ less than the average of the survey. European Commission's anti-corruption report (2014b) has revealed that 4 out of 10 companies identify corruption as a major problem. $50 \%$ of construction companies indicated, that often have to deal with bribery and nepotism. It was found that the size of the company has a lot of influence for corruption processes - if the company is smaller bribery and nepotism can do more damage. Corruption as a problem for business frequently mentioned construction companies in the Czech Republic (71\%), Portugal (68\%), Greece $(66 \%)$ and Slovakia (66\%) (European Commission 2014b). Results from this study suggest that a large part of society tolerates corruption and refuses to deal with the challenges anti-corruption measures. Rakauskiene and Chlivickas (2007) analysed gender asymmetry ir public finance of Lithuania. Study revealed, that women possess less of real estate and capital than men. Also women are less active in corruption processes - men's activities are much more corrupt. The labor market dominated by discrimination against women: they traditionally are empolyed in less productive and less profitable branches (Rakauskienè, Chlivickas 2007).

Table 3. European Commission research (Source: composed by the authors on the basis of "Eurobarometer 397" 2014a data)

In (OUR COUNTRY), do you think that the giving and taking of bribes and the abuse of power for personal gain are widespread among any of the following?

\begin{tabular}{l|c}
\hline Political parties & $59 \%$ \\
Politicians at national, regional or loval level & $56 \%$ \\
Officials awarding public tenders & $45 \%$ \\
Officials issuing building permits & $43 \%$ \\
Private companies & $38 \%$ \\
Police, customs & $36 \%$ \\
Banks and financial institutions & $36 \%$ \\
\hline
\end{tabular}


Continued Table 3

In (OUR COUNTRY), do you think that the giving and taking of bribes and the abuse of power for personal gain are widespread among any of the following?

\begin{tabular}{l|c}
\hline Inspectors (health and safety, construction control and licensing) & $\mathbf{3 5 \%}$ \\
\hline Healthcare & $33 \%$ \\
Officials issuing business permits & $33 \%$ \\
Tax authorities & $24 \%$ \\
The Courts & $23 \%$ \\
Public prosecution service & $19 \%$ \\
Social security and welfare authorities & $18 \%$ \\
The education sector & $16 \%$ \\
None & $5 \%$ \\
Don't know & $7 \%$ \\
\hline
\end{tabular}

In many countries of the world, the population is informed about the construction that is taking place in the last moment i.e. the purpose of recreational areas is changed and they become filled with apartment houses. In this case, the district's residents express their dissatisfaction with the ongoing construction and try to figure out where and how real estate developers received permits for construction. Building constructors are usually guided by the fact that the district residents do not participate in consideration of the detailed plan and do not express an opinion. Over the years, as the construction volumes grow, this problem will only increase, since there is a growing number of construction companies that are trying to obtain building permits in infrastructurally attractive locations with the help of bribes. The second problem is related to "developers of a single project". Developers of a single project are small companies that are created to implement a single real estate project and, after doing so, declare bankruptcy. For this reason, the customers lose all promised guarantees and are left with a defective product.

Socio-economic factors. Manifestations of the socio-economic problems - poverty, unemployment or poor access to mortgage - may have a significant impact on shaping public needs in a specific region. When potential customers choose home and decide on the property unit quadrature, class, or price, the choice can be influenced by social and demographic factors - increased unemployment, social exclusion and increasing migration. These indicators deteriorate, real estate market participants begin to evaluate their options more carefully, so, often, an apartment of smaller quadrature or price is chosen (Ādmīdiņš, Zvanīt 2011). The Dutch real estate market research carried out by scientists Greef and Haas (2000) has revealed that the price of housing is directly dependent on the country's GDP per capita, number of households, housing loans volume, which is also affected by the cost of housing. Also it was found that in long run housing prices ar influenced by factors such as demographic developments or housing stock (Greef, Haas 2000). Šileika and Andriušaitienè (2006) contucted a study that sought to determine the relation between labour market indicators and macroeconomic indicators. Results of the correlation analysis revealed that on national scale the unemployment rate indicator is correlated to the income of municipal budgets, budgetary expenses of the municipalities, financial investment, scale of works performed by construction companies and enterprises, municipal expenses for social benefits, rate of employment and longterm unemployment rate (Šileika, Andriušaitienè 2006).

Demographic challenges. In 2011, the population of the world has reached seven billion people. No wonder that for decades it comes to the so-called people's surplus - the level of risk, when population exceeds the planet's capacity to supply humanity housing, food and other resources. Following the data of the World bank (2016a), through the years 2011-2015, 179 countries with an increasing or stable number of residents have been identified. Only 33 countries have a population that continues to decline (World bank 2016a). It is estimated that in 2050 the human population will grow to 9.1 billion. Looking at these figures it can be assumed that the increase of population will naturally cause an increase in building density (real estate properties will be built within much smaller distance than usual). This means that, in the future, green and recreational areas may disappear in many countries, and public land will be privatized for the construction of residential houses. Due to the growing population the need for construction will increase, so all land within the city limits will be considerably more expensive. The research carried out by Moir et al. (2014) has revealed that population increase has led to the aquatic and air pollution processes, as well as a more rapid loss of green areas. Population density in urban areas grew much faster than in rural areas, especially in developing countries, causing additional environmental problems (Moir et al. 2014). Cohen (2006) predicts that by the year $2030,60 \%$ of the world's population will live in urban areas. Population growth is one of the major 21st century problems, the solution of which shall be made not only by international bodies but also public organizations (Cohen 2006). The author estimates that an efficiently managed system in small cities would make it easier to cope with emerging population growth challenges. According to the assessment of Wang et al. (2015), the urban development ideology must change, focusing 
more on migration, ageing and population growth problems. The above-named factors suggest that the growing population, as well as the pollution of urban areas will encourage the construction of more expensive to design, even higher energy class real estate objects, which would ensure the efficient use of renewable energy sources (Wang et al. 2015).

\section{The European Union's residential real estate market forecast for 2017}

The forecast objectively assessed the basic external problems affecting the real estate market, as well as discussed their influence on the current needs of society. The study was conducted based on the latest data available on the databases of Economywatch, International Monetary Fund, Numbeo, and Transparency International. Table 4 assesses the current 28 member states of the European Union.

Table 4. European Union residential real estate market: 2017's forecast (Source: composed by the authors of the basis of Economywatch 2017; IMF 2017; Numbeo 2017; Transparency International 2016; World Bank 2016b)

\begin{tabular}{|c|c|c|c|c|c|c|}
\hline EU State & Population & $\begin{array}{l}\text { GDP per } \\
\text { capita }\end{array}$ & $\begin{array}{l}\text { Corruption Percep- } \\
\text { tion Index }\end{array}$ & $\begin{array}{l}\text { Unemployment } \\
\text { rate }\end{array}$ & $\begin{array}{l}\text { Sq. m. price of } 3 \\
\text { bedrooms apart- } \\
\text { ment outside city } \\
\text { centre }\end{array}$ & $\begin{array}{c}\text { Rent price of } 3 \\
\text { bedrooms apart- } \\
\text { ment outside city } \\
\text { centre }\end{array}$ \\
\hline Belgium & $0.8 \% \uparrow$ & $3 \% \uparrow$ & $1 \% \uparrow$ & $-1.2 \% \downarrow$ & $-5 \% \downarrow$ & $-9 \% \downarrow$ \\
\hline Malta & $0.6 \% \uparrow$ & $6 \% \uparrow$ & $0 \% \rightarrow$ & $-1.9 \% \downarrow$ & $0 \% \rightarrow$ & $-1 \% \downarrow$ \\
\hline France & $0.5 \% \uparrow$ & $3 \% \uparrow$ & $0 \% \rightarrow$ & $-1.0 \% \downarrow$ & $8 \% \uparrow$ & $3 \% \uparrow$ \\
\hline Italy & $0.3 \% \uparrow$ & $2 \% \uparrow$ & $1 \% \uparrow$ & $-4.4 \% \downarrow$ & $-3 \% \downarrow$ & $-10 \% \downarrow$ \\
\hline Portugal & $-0.5 \% \downarrow$ & $3 \% \uparrow$ & $2 \% \uparrow$ & $-4.3 \% \downarrow$ & $3 \% \uparrow$ & $4 \% \uparrow$ \\
\hline Luxembourg & $2.4 \% \uparrow$ & $3 \% \uparrow$ & $-1 \% \downarrow$ & $-1.6 \% \downarrow$ & $-1 \% \downarrow$ & $2 \% \uparrow$ \\
\hline Germany & $0 \% \rightarrow$ & $3 \% \uparrow$ & $0 \% \rightarrow$ & $4.3 \% \uparrow$ & $1 \% \uparrow$ & $3 \% \uparrow$ \\
\hline Croatia & $-0.2 \% \downarrow$ & $4 \% \uparrow$ & $8 \% \uparrow$ & $-3.0 \% \downarrow$ & $-5 \% \downarrow$ & $-7 \% \downarrow$ \\
\hline Cyprus & $0.4 \% \uparrow$ & $3 \% \uparrow$ & $2 \% \uparrow$ & $-8.5 \% \downarrow$ & $-4 \% \downarrow$ & $-1 \% \downarrow$ \\
\hline Austria & $0.6 \% \uparrow$ & $3 \% \uparrow$ & $-1 \% \downarrow$ & $3.1 \% \uparrow$ & $1 \% \uparrow$ & $-4 \% \downarrow$ \\
\hline Hungary & $-0.1 \% \downarrow$ & $1 \% \uparrow$ & $7 \% \uparrow$ & $-4,5 \% \downarrow$ & $-3 \% \downarrow$ & $-1 \% \downarrow$ \\
\hline Netherlands & $0.3 \% \uparrow$ & $4 \% \uparrow$ & $0 \% \rightarrow$ & $-3.1 \% \downarrow$ & $1 \% \uparrow$ & $2 \% \uparrow$ \\
\hline Romania & $-0.2 \% \downarrow$ & $6 \% \uparrow$ & $4 \% \uparrow$ & $-3.1 \% \downarrow$ & $-2 \% \downarrow$ & $1 \% \uparrow$ \\
\hline Ireland & $0.1 \% \uparrow$ & $5 \% \uparrow$ & $1 \% \uparrow$ & $-9.6 \% \downarrow$ & $-8 \% \downarrow$ & $2 \% \uparrow$ \\
\hline Finland & $0.5 \% \uparrow$ & $3 \% \uparrow$ & $-1 \% \downarrow$ & $-3.2 \% \downarrow$ & $0 \% \rightarrow$ & $-2 \% \downarrow$ \\
\hline Greece & $-0.5 \% \downarrow$ & $5 \% \uparrow$ & $11 \% \uparrow$ & $-6.4 \% \downarrow$ & $-1 \% \downarrow$ & $-5 \% \downarrow$ \\
\hline Czech Republic & $0.2 \% \uparrow$ & $4 \% \uparrow$ & $6 \% \uparrow$ & $-2.1 \% \downarrow$ & $-1 \% \downarrow$ & $2 \% \uparrow$ \\
\hline Sweden & $0.8 \% \uparrow$ & $1 \% \uparrow$ & $-2 \% \downarrow$ & $2.9 \% \uparrow$ & $-2 \% \downarrow$ & $-1 \% \downarrow$ \\
\hline United Kingdom & $0.6 \% \uparrow$ & $-2 \% \downarrow$ & $1 \% \uparrow$ & $0 \% \rightarrow$ & $-18 \% \downarrow$ & $-9 \% \downarrow$ \\
\hline Bulgaria & $-0.6 \% \downarrow$ & $5 \% \uparrow$ & $8 \% \uparrow$ & $-8.1 \% \downarrow$ & $-2 \% \downarrow$ & $-2 \% \downarrow$ \\
\hline Poland & $0.0 \% \rightarrow$ & $5 \% \uparrow$ & $4 \% \uparrow$ & $0.0 \% \rightarrow$ & $-1 \% \downarrow$ & $-2 \% \downarrow$ \\
\hline Slovenia & $0.2 \% \uparrow$ & $4 \% \uparrow$ & $-1 \% \downarrow$ & $-3.8 \% \downarrow$ & $2 \% \uparrow$ & $1 \% \uparrow$ \\
\hline Latvia & $-1.0 \% \downarrow$ & $7 \% \uparrow$ & $8 \% \uparrow$ & $-4.2 \% \downarrow$ & $-1 \% \downarrow$ & $-1 \% \downarrow$ \\
\hline Slovakia & $0.0 \% \rightarrow$ & $5 \% \uparrow$ & $7 \% \uparrow$ & $-7.7 \% \downarrow$ & $-1 \% \downarrow$ & $-3 \% \downarrow$ \\
\hline Estonia & $-0.4 \% \downarrow$ & $5 \% \uparrow$ & $3 \% \uparrow$ & $0.0 \% \rightarrow$ & $-3 \% \downarrow$ & $-3 \% \downarrow$ \\
\hline Lithuania & $-1.6 \% \downarrow$ & $6 \% \uparrow$ & $8 \% \uparrow$ & $-1.2 \% \downarrow$ & $7 \% \uparrow$ & $4 \% \uparrow$ \\
\hline Denmark & $0.4 \% \uparrow$ & $4 \% \uparrow$ & $0 \% \rightarrow$ & $-3.3 \% \downarrow$ & $6 \% \uparrow$ & $0 \% \rightarrow$ \\
\hline Spain & $-0.2 \% \downarrow$ & $4 \% \uparrow$ & $-3 \% \downarrow$ & $-7.1 \% \downarrow$ & $3 \% \uparrow$ & $4 \% \uparrow$ \\
\hline
\end{tabular}

$(\uparrow)$ - growth rate; $(\downarrow)$ - rate decrease; $(\rightarrow)$ - no changes.

It is predicted that the population will grow in 15 European Union countries. Mainly in Luxembourg $(2.4 \%)$, Belgium (0.8\%) and Sweden (0.8\%). In United Kingdom during the 2017 the population is expected to rise to 400 thousand. It can be assumed that after "Brexit" referendum foreigners living there rushed to acquire the country's nationality. It is predicted that GDP per capita will grow in all Europe Union countries, except United Kingdom. It can be assumed that this decrease will be affected by the results of Brexit referendum and secession from the European Union procedures. European Union member commitment each year to accommodate a fixed number of refugees will have a significant impact on the corruption perception index - it may decline in 6 countries (especially Scandinavian). 
In order to ensure a secure future and opportunities to obtain citizenship, refugees are trying to integrate into the life of an economically stable countries. One of the most interesting 2017-year trend - a record decrease in the unemployment rate. It is predicted that unemployment rate will increase only in three European Union countries: Sweden $(2.9 \%)$, Austria (3.1\%) and Germany (4.3\%). A prospective study allowed verifying the external problems that affect the real estate market, which were identified and discussed in the theoretical part: "Brexit" referendum, corruption, population growth, as well as socio-economic indicators. British citizens should feel the biggest impact of change through the following 2 years. It is estimated that due to the "Brexit" referendum the country will experience a decrease in the share of GDP per capita, real estate per square meter, as well as a decrease in the price of rents. The referendum may also increase the rate of unemployment. According to the data presented in Table 4, it can be assumed that the real estate buyers chose Germany, France, Spain and Portugal in the search of new investment markets.

\section{Conclusions}

Scientific literature and statistical analysis of the results revealed that in the context of globalization, the residential real estate market is affected by external factors, which are closely related to the potential customers needs and changes in behaviour. Physical and economic characteristics of real estate make it an investment of exceptional nature, which requires specific knowledge and preparation before preparing to buy. Today's issues suggest that in the future it will not be enough to just assess the real estate price and location on their own, so it is it is necessary to pay more attention to external factors and the impact of globalization. The analysis of scientific literature that the opinions of the authors dealing in globalization processes do vary. There is disagreement on the concept of globalization, the essential features of the process and impact on today's society. After analysing different authors points of view, it was found that the most common aspect of the concept is the social aspect. Technological, economic and geographical aspects were identified as less significant. According to different researchers paradigmatic point of view, globalization can be defined as continuously ongoing revolutionary processes, affecting all areas of life (social, cultural, economic, political, technological) in which various standards, fields and models are disseminated, assimilated and updated.Upon analysing the peculiarities of the European Union countries the real estate markets, it can be said that the real estate sector is mostly influenced by changes in the economic status. It was found that the deteriorating economic indicators cause rising unemployment and intensify corruption. Despite the fact that the majority of threats existing in the real estate market have only short-term effects, their prevention should be given much more attention - potential buyers should be encouraged to take an interest not only in the economic situation (crisis, foreign direct investment component or the tax system) but also demographic or geopolitical situation.It is recommended to evaluate the impact of external factors not only in the country where the investment is estimated, but also in the entire region (the Baltic States, Scandinavian countries, the Benelux countries and so on). This would effectively assess the risk factors, which potential investors may be faced with.

\section{References}

Ādmīdiņš, D.; Zvanīt, J. 2011. Factors affecting the dwelling space market prices in Latvia, Intelectual Economics 4(12): 513-525. Bauman, Z. 2007. Globalization: the human consequences. New York: Columbia University Press.

Brodeur, A. 2015. Terrorism and employment: evidence from succesful and failed terror attacks. Discussion paper series 9526 (2015): 1-46.

Bryson, J. 2016. Brexit - now what, Wells Fargo Securities 8(15): 1-6.

Cohen, B. 2006. Urbanization in developing countries: current trends, future projections and key challenges for susitainability, Technology in Society 28(2006): 63-80. https://doi.org/10.1016/j.techsoc.2005.10.005

Cushman \& Wakefield. 2016. Brexit \& the European property investment market: capital views [online], [cited 2 February 2017]. Available from Internet: http://www.cushmanwakefield.com/ /media/global-reports/Capital_Views_EMEA_Brexit_July_ 16.pdf

Economywatch. 2017. Unemployment rate data for year 2017 [online], [cited 2 February 2017]. Available from Internet: http://www.economywatch.com/economic-statistics/economic-indicators/Unemployment_Rate_Percentage_of_Labour_Force/2017/

European Commission. 2014a. Special Eurobarometer 397: corruption report [online], [cited 4 February 2017]. Available from Internet: http://ec.europa.eu/public_opinion/archives/ebs/ebs_397_en.pdf

European Commission. 2014b. Report from the commission to the council and European Parliament: EU anti-corruption report [online], [cited 5 February 2017]. Available from Internet: https://ec.europa.eu/home-affairs/sites/homeaffairs/files/e-library/documents/policies/organized-crime-and-human-trafficking/corruption/docs/acr_2014_en.pdf

European Commission. 2016b. EU budget deal focuses on strenghthening the economy and responding to the refugee crisis[online], European Commission - press release [cited 1 February 2017]. Available from Internet: http://europa.eu/rapid/press-release_IP-16-3743_en.htm

European Commission. 2015. Standart Eurobarometer 84 [online], [cited 29 January 2017]. Available from Internet: http://ec.europa.eu/COMMFrontOffice/publicopinion/index.cfm/Survey/getSurveyDetail/instruments/STANDARD/surveyKy/2098 
European Commission. 2016a. Standart Eurobarometer 86 [online], [cited 3 February 2017]. Available from Internet: http://ec.europa.eu/COMMFrontOffice/publicopinion/index.cfm/Survey/getSurveyDetail/instruments/STANDARD/surveyKy/2137

Eurostat. 2017a. Asylum quaterly report [online], [cited 3 February 2017]. Available from Internet: http://ec.europa.eu/eurostat/statistics-explained/index.php/Asylum_quarterly_report

Eurostat. 2017b. Gross value added: real estate activities [online], [cited 2 February 2017]. Available from Internet: http://ec.europa.eu/eurostat/tgm/table.do?tab=table\&init=1\&language=en\&pcode=teina432_r2\&plugin=1

Giddens, A. 2005. Sociologija. Kaunas: Poligrafija ir informatika.

Greef, I.; Haas, R. 2000. Housing prices, bank lending and monetary policy, Research Series Supervision Paper 31(1): 1-22.

Held, D.; McGrew, A.; Goldblatt, D.; Perraton, J. 2002. Globaliniai pokyčiai: politika, ekonomika ir kultūra. Vilnius: Margi raštai.

IMF. 2017. GDP per capita [online], International monetary fund [cited 10 February 2017]. Available from Internet: http://statisticstimes.com/economy/countries-by-projected-gdp-capita.php

Institute for economic \& peace. 2016. Global terrorism index [online], [cited 5 February 2017]. Available from Internet: http://economicsandpeace.org/wp-content/uploads/2016/11/Global-Terrorism-Index-2016.2.pdf

JLL. 2016. Global real estate tranparency index [online], Jones Lang LaSalle [cited 12 February 2017]. Available from Internet: http://www.jll.com/Research/Global-Real-Estate-Transparency-Index-2016.pdf

Jones, S. 2015. The terrorism threat to the united states and implications for refugees, Rand corporation paper 433(2015): 1-11.

KPMG. 2011. Surveyon bribery and corruption. Impact on Economy and Business Environment [online], Klynveld, Peat Marvick and Goerdeler International [cited 8 February 2017]. Available from Internet: https://www.kpmg.com/Global/en/IssuesAndInsights/ArticlesPublications/Documents/bribery-corruption.pdf

Moir, E.; Moonen, T.; Clark, G. 2014. The future of cities: what is the global agenda? The business of cities 9(2014): 1-58.

Numbeo. 2017. Property prices [online], [cited 8 February 2017]. Available from Internet: https://www.numbeo.com/cost-of-living/historical-data-country

Rajaram, K. 2015. Refugees: geographical aspects, International Encyklopedia of the Social \& Behavioral Sciences 2015(19): 111116.

Rakauskienè, G. O.; Chlivickas, E. 2007. Public Finance of Lithuania: gender perspective, Journal of Business Economics and Management 8(1): 11-27.

Ravenhill, J. 2011. Global political economy. New York: Oxford University Press.

Robinson, I. W. 2007. Theories of globalization, Blackwell Publishing 4(3): 125-141. https://doi.org/10.1002/9780470691939.ch6

Sandler, T. 2014. The analytical study of terrorism: taking stock, Journal of Peace Research 51(2): 257-271. https://doi.org/10.1177/0022343313491277

Scholte, J. A. 2005. Globalization: a critical introduction. New York: Palgrave Macmillan. https://doi.org/10.1007/978-0-23021207-7

Šileika, A.; Andriušaitienè, A. 2006. Problems of identifying and regulating the structure of the labour market in depressive Lithuanian regions, Journal of Business Economics and Management 7(4): 223-233.

Steger, M. B. 2013. Globalization: a very short introduction. Oxford: Oxford University Press. https://doi.org/10.1093/actrade/9780199662661.001.0001

Transparency International. 2016. Corruption perception index [online], [cited 5 February 2017]. Available from Internet: http://www.transparency.org/research/cpi/overview

UNHCR.2016. Refugees / Migrants Emergency Responce - Mediterranean [online], United Nation Refugee Agency [cited 3 February 2017]. Available from Internet: http://data.unhcr.org/mediterranean/regional.php

Varma, S.; Gill, H. S. 2010. Developement strategies for inclusive cities. New Delhi: Response books.

Wang, Z.; Wang, C.; Zhang, Q. 2015. Population ageing, urbanization and housing demand, Journal of Service Science and Management 2015(8): 516-525.

Wells Fargo. 2015. Investment implications of Paris attacks [online], [cited 4 February 2017]. Available from Internet: https://www.wellsfargo.com/the-private-bank/insights/investing/gisr-investment-implications-paris-attacks/

World bank. 2016a. Total population in different world countries [online], [cited 7 February 2017]. Available from Internet: http://data.worldbank.org/indicator/SP.POP.TOTL

World bank. 2016b. Population estimates and projections [online], [cited 8 February 2017]. Available from Internet: http://data.worldbank.org/data-catalog/population-projection-tables 